\title{
Improving Security and Safety Issues Data Stored in Cloud
}

\author{
N.Sivaranjani, Amudha S, Mary Linda I
}

\begin{abstract}
Cloud computing is being progressively patronized by each organizations and folks World Health Organization have robust interest and investment from government and sectors. Cloud primarily based services have fully grown to be a part of our day-to- day package solutions. In this, the most security and safety issues embody secure storage, secure access and secure retrieval. However, authentication alongside access management and trust calculation and management connected with cloud service suppliers (CSPs) unimaginable and barely researched problems for this new paradigm. During this article, we have a tendency to discuss various information accessibility supported trust parameters among CSP and conductor.
\end{abstract}

Keywords-Access management, Cloud storage, Role, Trust, Security

\section{INTRODUCTION}

Cloud computing is one in all the foremost eminent technologies in IT sectors. It composed of service orientated design (SOA), virtualization, completely different services and readying design. It offers services during a pay-as-you-use procedure. It's several options (i.e.

Cost, measurability, on-demand access) to use the resources effectively and every one the users comprehend cloud blessings, the difficult task is to supply a robust security and storage mechanisms attributable to its web primarily based storage and management of knowledge. Most of knowledge| stored in clouds are sensitive/confidential data of a enterprise, as an example Medical knowledge, Military info and social networks. The necessary duty to achieving the bigger security and privacy of the information. For this we've got to supply robust authentication and access management mechanism technique.[8]

Access management is one in all the elemental demands so as to avoid unauthorized access to programs and shield organization's assets. customary Access management Models ar necessary Access management (MAC) and Role primarily based Access management (RBAC).Each one of those models is thought as identification primarily based access management models. all told these access management models, user (subjects) further as resources (objects) is

Revised Manuscript Received on December 11, 2019

N.Sivaranjani, Department of Computer science and Engineering, Bharath Institute of Higher Education and Research, Chennai, Tamilnadu, India. Email: ranjibalas@gmail.com

Amudha S, Department of Computer science and Engineering, Bharath Institute of Higher Education and Research, Chennai, Tamilnadu, India.. Email: amudha17s@gmail.com

Mary Linda I, Department of Computer science and Engineering, Bharath Institute of Higher Education and Research, Chennai, Tamilnadu, India. Email: catchlin.18@gmail.com thought to be distinctive names. Identification could also be done or through roles assigned to the themes directly. These access management techniques ar effective in unalterable distributed system, wherever there's solely an inventory of Users with a better-known list of services. Access management techniques perform authorization identification, authentication, access approval, and responsibilities of entities through login credentials together with passwords; personal identification numbers (PINs), biometric scans, and physical or could also be electronic keys.[9]

\section{RELATED WORKS}

1. The significance of ensuring the remote information trustworthiness has been featured by the consequent examination. Works underneath totally extraordinary security models and these are regularly useful to ensure the capacity accuracy while not having clients having local learning region unit all gaining practical experience in single server scenario[1] obvious information ownership model for ensuring ownership of document on untrusted storages. Although direct applying these systems to different servers might be basic, the came about confirmation would be straight to the measure of servers.

2. Jules et al. plot a legitimate "confirmation of retrivabilty"(POR) model for ensuring the remote information respectability, their topic joins spot-checking also as blunder rectifying code to ensure every belonging and getting of documents on file administration frameworks.3.

Bowers et al. extended "proof of retrivabilty"(POR) model to appropriated frameworks, of these plans are spend significant time in static learning. The viability of their subject lays essentially on the proposing steps that the client leads before re-appropriating the data document. Any adjustment to the substance of data record, even couple of bits ought to engender through the mistake rectifying code and in this way the comparing irregular rearranging strategy, along these lines Introducing significant calculation and correspondence multifaceted nature, however the token pre-calculation of the labels forces noteworthy calculation overhead that might be important for Associate in Nursing entire document.

\section{ACCESS MANAGEMENT AND TRUST}

An old school job based access the executives style alternatives intelligently separate client and consent. Every connection by methodology of job is first of all, connection is 
really accomplished by means of client task among client and position; optional, relationship is gotten through consent task among job and Permission; in the end, the relationships among's client and job.

Also, in the middle of job and authorization would conceivably arrive at the Correlation in regards to client and permission.[7] Under cloud atmosphere, the trustworthy relationship typically has 3 classes. Directed, Undirected, counseled sure relationship. It will be supported interaction record between network entities to judge the believability among the antecedently mentioned 3 trustworthy relationships.[1-2]

However the combination of trust and access management technique has 2 necessary problems to supply a security and secure access management

a) Authentication of CSP and CSU: Authentication and authorization is base for providing sensible access management for user knowledge, that ar keep on a cloud server. In our framework supports multifactor authentication to access the resources on cloud service suppliers.

b) Trust primarily based Access management Mechanism: In recent years all the enterprise knowledge ar actuated to cloud. knowledge|the info|the information \} will be sensitive data (Medical data), personal info (credit card, social networks data). thus to stay this knowledge during a secure manner we'd like a secure and economical access management technique is needed for cloud. In our projected framework we have a tendency to introduce a brand new access management model, that is predicated on trust level of CSP.[3]

\section{AUTHENTICATION}

We will find generous works concerning validation in Cloud. for instance, an individual confirmation structure for $\mathrm{CC}$ is anticipated, pointing on giving ease of use, character overseeing, shared verification and session key understanding between the top clients and furthermore the cloud server. Giving extraordinary consideration to the light-weight identified with validation since the cloud oversees gigantic measures of information in timespan, a light-weight multi-client confirmation subject dictated by cell automata in cloud facilitating climate. Testament authority organized one-time parole validation is valuable to perform confirmation. Supporting mysterious confirmation, a restricted availability the executives subject for ensured information stockpiling in mists. They anticipated subject conveys client repudiation, avoids re-run assaults further as encourages creation, adjustment and perusing information keep inside the cloud. tuning in to the negative marks of dropping affluent data just nearby the terrible showings following from the specific propelled contributions of typical unique mark acknowledgment approaches all through client confirmation, it talks about a fresh out of the plastic new finger impression acknowledgment structure bolstered a gathering of amassed geometric minute and Zernike moment choices to ensure clients all through distributed computing interchanges

\section{TRUST AND NAME}

There is a spread of analysis works with relation to trust or trait of cloud. as an example, that specialize in the particular trait of the cloud solutions, a framework is usually recommended to judge the cloud solutions trait, by utilizing armor so as to perpetually monitor and confirm the cloud atmosphere further as observing the resources the armor guards. For economical reconfiguration additionally to allocation of cloud process resources to satisfy numerous user requests, a trust style that collects and evaluates the reliableness of cloud hosting resources supported the historical details of servers is contains, in order that the most effective obtainable cloud hosting resources to meet the user demands will be ready earlier. to appear for the believability of trust evaluations further as managing trust evaluations in cloud environments, a brand new framework named trust since service to boost current believe managements, by introducing a good accommodative believability model to seek out the credible and prejudicious feedbacks. Discussing the cloud hosting answerableness issue, it terribly at first uses detective controls to handle the key problems to ascertain a reliable cloud and so provides a believer in cloud framework consisted of a number of abstraction layers, wherever technological and policy-based approaches ar typically applied to deal with answerableness.

\section{RESULTS}

A cloud supplier might be a business undertaking that gives some piece of distributed computing - ordinarily Infrastructure as a Service, programming program gadget as a Service Platform as a Service - to elective organizations or individuals. Cloud suppliers region unit by and large expressed as cloud transporter suppliers

a) IAAS

Foundation as a Service (IaaS) can be a type of distributed computing that has pictured registering resources over the net. is viewed as one of 3 most significant exercises of distributed computing contributions, on board programming machine as a Serviceand Platform as a Service

\section{b) $S A A S$}

Programming as a bearer (SaaS) might be a product program framework appropriation form inside which a third birthday celebration party seller has applications and makes them accessible to clients over the web. is one of 3 significant guidelines of distributed computing, on board foundation as a supplier (IaaS) and stage as a supplier

\section{c) $P A A S$}

Stage as a help can be a disseminated processing model that can give programs over the web. In a very PaaS variation, a cloud supplier supplies

hardware and programming structure contraptions - in some cases those required for application improvement - to its customers as a carrier. A PaaS provider has the hardware and programming program structure without anyone else unique establishment.

Blue Eyes Intelligence Engineering 
As a last item, PaaS frees customers from presenting in-residence hardware and programming gadget to widen or run a fresh out of the box new programming.

\section{VI.CONCLUSION}

Cloud based services have absolutely grown to be part of our day-to- day package deal solutions. In this, the most security and protection problems encompass relaxed storage, comfortable access and comfortable retrieval.

\section{REFERENCES}

1. Kumaravel A., Meetei O.N.,An application of non-uniform cellular automata for efficient cryptography,2013 IEEE Conference on Information and Communication Technologies, ICT 2013,V-,I-,PP-1200-1205,Y-2013

2. Kumarave A., Rangarajan K.,Routing alogrithm over semi-regular tessellations, 2013 IEEE Conference on Information and Communication Technologies, ICT 2013,V-,I-,PP-1180-1184,Y-2013

3. Dutta P., Kumaravel A.,A novel approach to trust based identification of leaders in social networks,Indian Journal of Science and Technology,V-9,I-10,PP--,Y-2016

4. Kumaravel A., Dutta P.,Application of Pca for context selection for collaborative filtering,Middle - East Journal of Scientific Research,V-20,I-1,PP-88-93,Y-2014

5. Kumaravel A., Rangarajan K.,Constructing an automaton for exploring dynamic labyrinths,2012 International Conference on Radar, Communication and Computing, ICRCC 2012,V-,I-,PP-161-165,Y-2012

6. Kumaravel A.,Comparison of two multi-classification approaches for detecting network attacks, World Applied Sciences Journal,V-27,I-11,PP-1461-1465,Y-2013

7. Tariq J., Kumaravel A.,Construction of cellular automata over hexagonal and triangular tessellations for path planning of multi-robots,2016 IEEE International Conference on Computational Intelligence and Computing Research, ICCIC 2016,V-,I-,PP--,Y-2017

8. Sudha M., Kumaravel A.,Analysis and measurement of wave guides using poisson method,Indonesian Journal of Electrical Engineering and Computer Science,V-8,I-2,PP-546-548,Y-2017

9. Ayyappan G., Nalini C., Kumaravel A.,Various approaches of knowledge transfer in academic social network,International Journal of Engineering and Technology,V-,I-,PP-2791-2794,Y-2017

10. Kaliyamurthie, K.P., Sivaraman, K., Ramesh, S. Imposing patient data privacy in wireless medical sensor networks through homomorphic cryptosystems 2016, Journal of Chemical and Pharmaceutical Sciences

11. Kaliyamurthie, K.P., Balasubramanian, P.C. An approach to multi secure to historical malformed documents using integer ripple transfiguration 2016 Journal of Chemical and Pharmaceutical Sciences 9

12. A.Sangeetha,C.Nalini,'Semantic Ranking based on keywords extractions in the web", International Journal of Engineering \& Technology, 7 (2.6) (2018) 290-292

13. S.V.GayathiriDevi,C.Nalini,N.Kumar,"An efficient software verification using multi-layered software verification tool "International Journal of Engineering \& Technology, 7(2.21)2018 454-457

14. C.Nalini,ShwtambariKharabe,"A Comparative Study On Differen Techniques Used For Finger - Vein Authentication", International Journal Of Pure And Applied Mathematics, Volume 116 No. 82017 , 327-333, Issn: 1314-3395

15. M.S. Vivekanandan and Dr. C. Rajabhushanam, "Enabling Privacy Protection and Content Assurance in Geo-Social Networks", International Journal of Innovative Research in Management, Engineering and Technology, Vol 3, Issue 4, pp. 49-55, April 2018.

16. Dr. C. Rajabhushanam, V. Karthik, and G. Vivek, "Elasticity in Cloud Computing", International Journal of Innovative Research in Management, Engineering and Technology, Vol 3, Issue 4, pp. 104-111, April 2018.

17. K. Rangaswamy and Dr. C. Rajabhushanamc, "CCN-Based Congestion Control Mechanism In Dynamic Networks", International Journal of Innovative Research in Management, Engineering and Technology, Vol 3, Issue 4, pp. 117-119, April 2018

18. Kavitha, R., Nedunchelian, R., "Domain-specific Search engine optimization using healthcare ontology and a neural network backpropagation approach", 2017, Research Journal of Biotechnology, Special Issue 2:157-166

19. Kavitha, G., Kavitha, R., "An analysis to improve throughput of high-power hubs in mobile ad hoc network" ,2016, Journal of Chemical and Pharmaceutical Sciences, Vol-9, Issue-2: 361-363

20. Kavitha, G., Kavitha, R., "Dipping interference to supplement throughput in MANET" , 2016, Journal of Chemical and Pharmaceutical Sciences, Vol-9, Issue-2: 357-360

21. Michael, G., Chandrasekar, A.,'Leader election based malicious detection and response system in MANET using mechanism design approach", Journal of Chemical and Pharmaceutical Sciences(JCPS) Volume 9 Issue 2, April - June 2016

22. Michael, G., Chandrasekar, A.,"Modeling of detection of camouflaging worm using epidemic dynamic model and power spectral density", Journal of Chemical and Pharmaceutical Sciences(JCPS) Volume 9 Issue 2, April - June 2016.

23. Pothumani, S., Sriram, M., Sridhar, J., Arul Selvan, G., Secure mobile agents communication on intranet,Journal of Chemical and Pharmaceutical Sciences, volume 9, Issue 3, Pg No S32-S35, 2016

24. Pothumani, S., Sriram, M., Sridhar , Various schemes for database encryption-a survey, Journal of Chemical and Pharmaceutical Sciences, volume 9, Issue 3, Pg NoS103-S106, 2016

25. Pothumani, S., Sriram, M., Sridhar, A novel economic framework for cloud and grid computing, Journal of Chemical and Pharmaceutical Sciences, volume 9, Issue 3, Pg No S29-S31, 2016

26. Priya, N., Sridhar, J., Sriram, M. "Ecommerce Transaction Security Challenges and Prevention Methods- New Approach" 2016 ,Journal of Chemical and Pharmaceutical Sciences, JCPS Volume 9 Issue 3.page no:S66-S68

27. Priya, N.,Sridhar,J.,Sriram, M."Vehicular cloud computing security issues and solutions" Journal of Chemical and Pharmaceutical Sciences(JCPS) Volume 9 Issue 2, April - June 2016

28. Priya, N., Sridhar, J., Sriram, M. "Mobile large data storage security in cloud computing environment-a new approach” JCPS Volume 9 Issue 2. April - June 2016

29. Anuradha.C, Khanna.V, "Improving network performance and security in WSN using decentralized hypothesis testing "Journal of Chemical and Pharmaceutical Sciences(JCPS) Volume 9 Issue 2, April - June 2016.

\section{AUTHORS PROFILE}

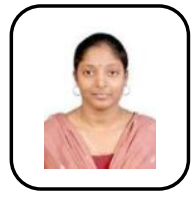

N.Sivaranjani Assistant Professor, Department of Computer science and Engineering, Bharath Institute of Higher Education and Research, Chennai, India

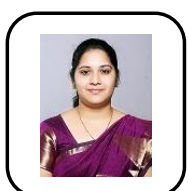

Amudha S Assistant Professor, Department of Computer science and Engineering, Bharath Institute of Higher Education and Research, Chennai, India

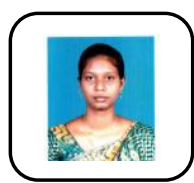

Mary Linda I Assistant Professor, Department of Computer science and Engineering, Bharath Institute of Higher Education and Research, Chennai, India 